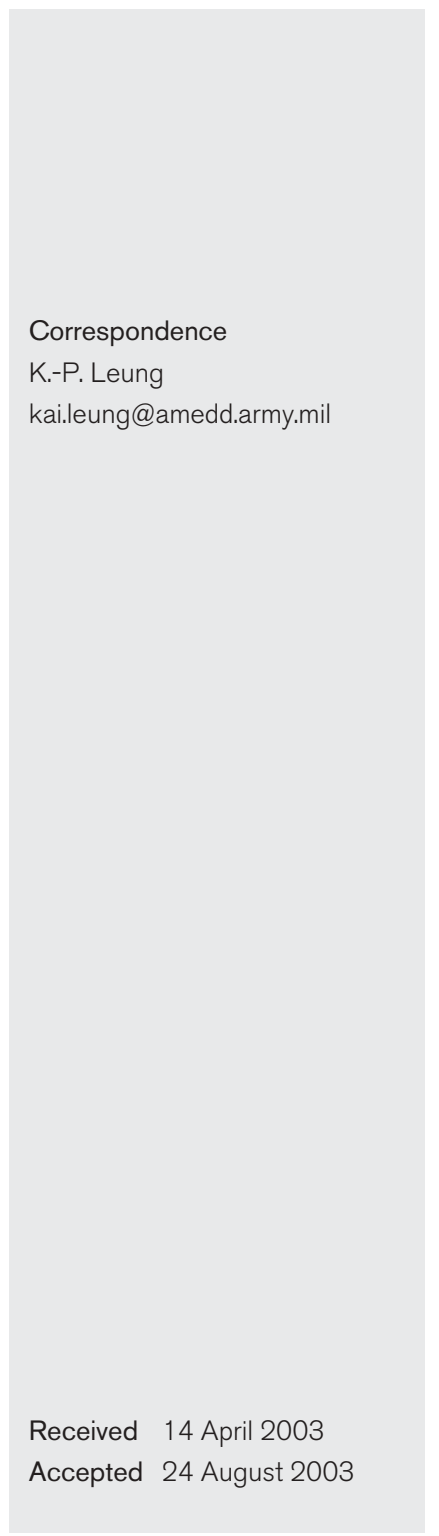

\title{
Susceptibility of oral bacteria to an antimicrobial decapeptide
}

\author{
S. P. Concannon, ${ }^{1}$ † T. D. Crowe, ${ }^{1}$ J. J. Abercrombie, ${ }^{1}$ C. M. Molina, ${ }^{1}$ P. Hou, ${ }^{1}$ \\ D. K. Sukumaran, ${ }^{2}$ P. A. Raj ${ }^{3}$ and K.-P. Leung ${ }^{1}$ \\ ${ }^{1}$ Microbiology Branch, US Army Dental Research Detachment, Walter Reed Army Institute of \\ Research, Great Lakes, IL 60088, USA \\ ${ }^{2}$ Department of Chemistry, State University of New York at Buffalo, Buffalo, NY 14260, USA \\ ${ }^{3}$ School of Dentistry, Marquette University, Milwaukee, WI 53233, USA
}

\begin{abstract}
Naturally occurring antimicrobial peptides have emerged as alternative classes of antimicrobials. In general, these antimicrobial peptides exhibit selectivity for prokaryotes and minimize the problems of engendering microbial resistance. As an alternative method to search for more effective broadspectrum peptide antimicrobials, investigators have developed peptide libraries by using synthetic combinatorial technology. A novel decapeptide, KKVVFKVKFK (KSL), has been identified that shows a broad range of antibacterial activity. The purpose of this study was to test the efficacy of this antimicrobial peptide in killing selected strains of oral pathogens and resident saliva bacteria collected from human subjects. Cytotoxic activity of KSL against mammalian cells and the structural features of this decapeptide were also investigated, the latter by using two-dimensional NMR in aqueous and DMSO solutions. MICs of KSL for the majority of oral bacteria tested in vitro ranged from 3 to $100 \mathrm{~g} \mathrm{~m} \mathrm{~m}^{-1}$. Minimal bactericidal concentrations of KSL were, in general, within one to two dilutions of the MICs. KSL exhibited an $\mathrm{ED}_{99}$ (the dose at which $99 \%$ killing was observed after 15 min at $37^{\circ} \mathrm{C}$ ) of $6.25 \mu \mathrm{g} \mathrm{ml}^{-1}$ against selected strains of Lactobacillus salivarius, Streptococcus mutans, Streptococcus gordonii and Actinobacillus actinomycetemcomitans. In addition, KSL damaged bacterial cell membranes and caused $1.05 \mathrm{log}$ units reduction of viability counts of saliva bacteria. In vitro toxicity studies showed that $\mathrm{KSL}$, at concentrations up to $1 \mathrm{mg} \mathrm{ml}^{-1}$, did not induce cell death or compromise the membrane integrity of human gingival fibroblasts. NMR studies suggest that KSL adopts an $\alpha$-helical structure in DMSO solution, which mimics the polar aprotic membrane environment, whereas it remains unstructured in aqueous medium. This study shows that KSL may be a useful antimicrobial agent for inhibiting the growth of oral bacteria that are associated with caries development and early plaque formation.
\end{abstract}

\section{INTRODUCTION}

We have witnessed the declining efficacy of conventional antibiotics in recent years, due to the progressive increase and proliferation of antibiotic-resistant organisms (Davies, 1994; Schutze et al., 1994). The discovery of a large number of naturally occurring invertebrate and vertebrate antimicrobial peptides has resulted in the emergence of alternative

tPresent address: Wyeth BioPharma, St Louis, MO 63134, USA.

Abbreviations: CD, circular dichroism; DMF, N,N-dimethylforamide; DQFCOSY, double quantum-filtered correlated spectroscopy; Fmoc, 9fluorenylmethoxycarbonyl; HGF, human gingival fibroblasts; LDH, lactate dehydrogenase; MALDI-TOF, matrix-assisted laser desorption/ ionization-time of flight; MBC, minimal bactericidal concentration; MTT, 3(4,5-dimethylthiazol-2-yl)-2,5-diphenyltetrazolium bromide; NOE, nuclear Overhauser effect; NOESY, nuclear Overhauser effect spectroscopy; RMSD, root mean square deviation; TOCSY, total correlated spectroscopy. classes of peptide antibiotics that exhibit selectivity for prokaryotes and minimize the problems of introducing microbial resistance (Boman, 1998; Hancock \& Lehrer, 1998; Hancock \& Chapple, 1999; Nizet et al., 2001; Zasloff, 2002). These peptide antibiotics interact directly with microbial surfaces, often leading to the formation of pores or in some way compromising membrane permeability (Zasloff, 1992; Hancock, 1997a; Hancock \& Rozek, 2002; Koczulla \& Bals, 2003; Yeaman \& Yount, 2003). Aside from their antimicrobial activities, some of these peptides also possess other biological activities that have impacts on cell proliferation, immune induction, cytokine release, chemotaxis and tissue repair (Bateman et al., 1991; Elsbach, 2003; Koczulla \& Bals, 2003; Koczulla et al., 2003).

In general, antimicrobial peptides exhibit diverse structures; however, most are cationic amphiphilic molecules because of 
the presence of arginine and lysine residues and can be grouped into four or five different structural categories. These include: (a) cysteine-rich, amphiphilic $\beta$-sheet peptides ( $\alpha$ - and $\beta$-defensins, protegrins and tachyplesins); (b) cysteine-disulfide ring peptides with or without amphiphilic tails (bactenecin, ranalexin and brevinins); (c) amphiphilic $\alpha$-helical peptides without cysteine (magainins and cecropins); and (d) linear peptides ( $\mathrm{Bac} 5, \mathrm{Bac} 7$, PR39 and indolicidin) with one or two predominant amino acids (proline or tryptophan) (Hancock et al., 1995; Hancock, 1997b; Hancock \& Lehrer, 1998; Henderson et al., 1998).

Many synthetic analogues of these peptides have been created in attempts to improve the antimicrobial activity of some of these naturally occurring antibacterial peptides (Wade et al., 1992; Tamamura et al., 1995; Helmerhorst et al., 1997; Fuchs et al., 1998; Chen et al., 2000; Mosca et al., 2000; Rothstein et al., 2001). For example, Dhvar 5, an analogue of histatin 5, one of the antimicrobial histatin peptides that are derived from saliva (Helmerhorst et al., 1999; Mickels et al., 2001) and IB-367, an analogue of protegrins, antimicrobial peptides that were isolated from porcine leukocytes (Zhao et al., 1994; Chen et al., 2000; Mosca et al., 2000), are more effective in inhibiting bacterial growth and are synthesized more easily than their native counterparts.

In addition to the identification of these natural antimicrobial peptides and their synthetic analogues, investigators have developed peptide libraries by using synthetic combinatorial technology (Blondelle et al., 1994, 1996a, b; Blondelle \& Houghten, 1996; Hong et al., 1998; Boggiano et al., 2003) to search for more effective broad-spectrum peptide antimicrobials. Using this technology, Hong et al. (1998) identified a novel decapeptide, KKVVFKVKFK, that shows a broad range of antibacterial activity. This peptide antimicrobial is effective in inhibiting the growth of methicillin-resistant Staphylococcus aureus (MRSA), Pseudomonas aeruginosa and number of enterics. In addition, this peptide inhibits the growth of Candida albicans irreversibly, suggesting that this agent also possesses antifungal activity (Hong et al., 1998).

In this report, we describe the three-dimensional structure of this decapeptide in aqueous solution and in membrane environments, the effects of this antimicrobial peptide on oral bacteria that are involved in the formation of dental plaque and the development of caries and the interactions of this molecule with human gingival fibroblasts (HGF) for any cytotoxic effects associated with this peptide.

\section{METHODS}

Bacterial strains. Strains used in this study included American Type Culture Collection (ATCC) and laboratory strains of different oral bacteria. These included: Actinomyces naeslundii strain T14V-J1, Actinomyces israelii ATCC 10049, Streptococcus mutans strains LT11 and ATCC $25175^{\mathrm{T}}$, Streptococcus sobrinus ATCC $33478^{\mathrm{T}}$, Streptococcus gordonii strains DL1 and ATCC 51656, Streptococcus sanguinis strains SK36 and ATCC $10556^{\mathrm{T}}$, Streptococcus salivarius ATCC 9222, Streptococcus mitis ATCC 15913, Streptococcus oralis ATCC $35037^{\mathrm{T}}$, Lactoba- cillus salivarius ATCC 29602, Lactobacillus acidophilus ATCC $4357^{\circledR}$ and Actinobacillus actinomycetemcomitans ATCC 43718. S. mutans strain LT11 was kindly provided by Lin Tao, University of Illinois at Chicago, IL, USA. S. gordonii DL1 and S. sanguinis SK36 were provided by John Cisar, National Institute of Dental and Craniofacial Research, NIH, Bethesda, MD, USA.

Synthesis of the antimicrobial decapaptide KSL. KSL (KKVVFKVKFK- $\mathrm{NH}_{2}$ ) was synthesized by standard solid-phase procedures as described by Hong et al. (1998) by using 9-fluorenylmethoxycarbonyl (Fmoc) chemistry on a model 90 automatic peptide synthesizer (Advanced ChemTech). The peptide was synthesized on Rink amide methylbenzhydrylamine (MBHA) resin (AnaSpec) with the first $N$-Fmoc-protected Lys attached. Sequential coupling of protected Fmoc amino acids, which included Phe, Lys and Val, was done in $N^{\prime}$-tetramethyluronium tetrafluoroborate (TBTU) dissolved in $N, N$ dimethylforamide (DMF) that contained $0.55 \mathrm{M} \mathrm{N}, N^{\prime}$-diisopropylethylamine (DIEA) (all from Advanced ChemTech). Piperdine [20\% $(\mathrm{v} / \mathrm{v})$ in DMF] was used to remove the N-terminal Fmoc moiety from the growing peptide prior to subsequent coupling. Completion of coupling reactions was assessed by the ninhydrin test of Kaiser et al. (1970). Cleavage of the peptide from the resin and the deprotection of side chains were done by using a mixture of $95 \%$ trifluoroacetic acid and $5 \%$ ethane dithiol. Synthetic peptides were purified by reversephase HPLC (series 1100; Hewlett Packard) by using a Vydac C18 column. Peptide purity was confirmed by MALDI-TOF (matrixassisted laser desorption/ionization-time of flight) MS, as performed by the laboratories of AnaSpec. The final product was stored in lyophilized form at $-20{ }^{\circ} \mathrm{C}$ until use.

NMR structural analysis. Purified peptide $(7 \mathrm{mg})$ was dissolved in $630 \mu \mathrm{l}$ double-distilled water and $70 \mu{ }^{2} \mathrm{H}_{2} \mathrm{O}$ (Cambridge Isotope Laboratories) at a peptide concentration of $\sim 5 \mathrm{mM}$. The $\mathrm{pH}$ of the aqueous peptide solution was $3 \cdot 8$. For NMR experiments in DMSO, peptide (7 mg) was dissolved in $700 \mu \mathrm{l} 99.9 \%\left(\mathrm{C}^{2} \mathrm{H}_{3}\right)_{2} \mathrm{SO}$ (Cambridge Isotope Laboratories). One-dimensional (1D) and two-dimensional (2D) NMR experiments used for conformational analyses were performed at $30{ }^{\circ} \mathrm{C}$ in these solvents. All NMR experiments were carried out at $500 \mathrm{MHz}$ on a Varian Unity Inova spectrometer equipped with a SUN Sparcstation 20.1D-NMR spectra were recorded with a spectral width of $5000 \mathrm{~Hz}$ and a relaxation delay time of $2.5 \mathrm{~s}$, using $8 \mathrm{~K}$ data points zerofilled to $32 \mathrm{~K}$ before Fourier transformation. All 2D experiments were multiplied by a phase-shifted sine bell function in both dimensions and zero-filled prior to Fourier transformation, in order to achieve appropriate resolution in each dimension. Nuclear Overhauser effect spectroscopy (NOESY), double quantum-filtered correlated spectroscopy (DQF-COSY) and total correlated spectroscopy (TOCSY) experiments were performed by using standard methods, as described in our previous studies (Raj et al., 1998, 2000a). Coupling constant $\left(J_{\mathrm{NH}-\mathrm{C}^{\alpha} \mathrm{H}}\right)$ values were determined either from the resolved 1D spectra (digital resolution, $0 \cdot 1 \mathrm{~Hz}$ ) or from high-resolution DQF-COSY spectra. Hydrogen-deuterium $\left({ }^{1} \mathrm{H}-{ }^{2} \mathrm{H}\right)$ exchange of amide groups and variable temperature experiments were performed as described previously (Raj et al., 1998).

For structure calculation, ${ }^{1} \mathrm{H}-{ }^{1} \mathrm{H}$ distances for structure determination were deduced from nuclear Overhauser effect (NOE) cross-peak intensities in the 2D-NOESY spectrum, obtained with $150 \mathrm{~ms}$ mixing time in water. The $\mathrm{C}^{\beta \mathrm{H}} / \mathrm{C}^{\beta \mathrm{H}^{\prime}}$ cross-peak of Phe5 was selected as the reference to calibrate the intensities against known distances. Dihedral $\phi$ angle restraints were obtained from $J_{\mathrm{NH}-\mathrm{C}^{a} \mathrm{H}}$ via the Karplus equation (Pardi et al., 1984). A total of 135 NOE constraints, $d_{\alpha \mathrm{N}}(i, i+1), d_{\alpha \mathrm{N}}$ $(i, i), d_{\beta \mathrm{N}}(i, i), d_{\alpha \delta}(i, i+3), d_{\alpha \alpha}(i, i+1)$ and side chain interproton distances were used as parameters for structure determination. Distance geometry calculations were performed on a Silicon Graphics 4D/35 
workstation. Restrained energy minimization and structure analysis were carried out by using the SYBYL 6.02 molecular modelling package (Tripos Associates) on an Evans \& Sutherland ESV3 workstation.

Media, culture conditions and in vitro susceptibility tests. ToddHewitt broth (THB), brain heart infusion (BHI) broth, Todd-Hewitt agar (THA), trypticase soy agar (TSA), lactobacilli MRS (MRS) broth, Actinomyces broth and Mueller-Hinton broth (MHB) were purchased from Becton Dickinson. Blood agar plates (BAP) were prepared by supplementing TSA with $5 \%$ sheep blood (PML Microbiologicals). All cultures, except for Actinobacillus actinomycetemcomitans, S. mitis and Actinomyces israelii, were grown at $37^{\circ} \mathrm{C}$ in room air. Actinobacillus actinomycetemcomitans cultures were grown on BAP or in $\mathrm{MHB}$

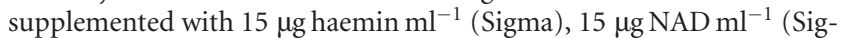
ma) and $5 \%$ yeast extract (Becton Dickinson) at $37^{\circ} \mathrm{C}$ in $5 \% \mathrm{CO}_{2} . \mathrm{S}$. mitis was grown on BAP or in BHI broth at $37^{\circ} \mathrm{C}$ in $5 \% \mathrm{CO}_{2}$. Actinomyces israelii was grown anaerobically in an anaerobic chamber (Coy Laboratory Products) in a $5 \% \mathrm{CO}_{2} / 10 \% \mathrm{H}_{2} / 85 \% \mathrm{~N}_{2}$ atmosphere.

MICs were determined as described by Fuchs et al. (1998) with a slight modification. Procedures were based on the National Committee for Clinical Laboratory Standards broth microdilution method. MHB was used as the main assay medium for most of the tested organisms. Freshly grown cultures at exponential phase were used as the inoculum. Bacteria were centrifuged at 4000 r.p.m. for $15 \mathrm{~min}$ at $4{ }^{\circ} \mathrm{C}$, suspended in $2 \times$ concentrated medium and adjusted to $4 \times 10^{6}$ c.f.u. $\mathrm{ml}^{-1}$ in $2 \times$ concentrated medium. Aqueous peptide solution $(100 \mu \mathrm{l})$ was added to each well of a 96-well, flat-bottomed plate (Becton Dickinson). The peptide solution was serially diluted (twofold) with sterile distilled water in the wells, with final peptide concentrations ranging from 3.13 to $200 \mu \mathrm{g} \mathrm{ml}^{-1}$. After dispensing $100 \mu \mathrm{l}$ aliquots of bacterial suspension into the wells, the 96 -well plates were incubated at $37^{\circ} \mathrm{C}$ for $24-48 \mathrm{~h}$ in room air, $\mathrm{CO}_{2}$ or anaerobically. The MIC was defined as the lowest concentration of the peptide that prevented visible turbidity, as measured at $600 \mathrm{~nm}$ by using an ELISA reader (Titertek Multiskan MCC/ 340). Visible turbidity was determined by the OD readings of tested samples that were significantly greater than that of the medium, i.e. background. Minimum bactericidal concentrations (MBCs) were determined by spiral-plating (Spiral Plater Autoplate 4000; Spiral Biotech) $50 \mu \mathrm{l}$ from each clear well ( $\geqslant \mathrm{MIC}$ ) onto BAP. After incubation for $24-48 \mathrm{~h}$, the $\mathrm{MBC}$ was determined as the lowest concentration that did not permit visible growth on the surface of the agar. For the susceptibility study, a small peptide at $200 \mu \mathrm{g} \mathrm{ml}^{-1}$, which had a sequence of LYPQPYQPQYQQYTF, and amoxicillin at $5 \mu \mathrm{g} \mathrm{ml}^{-1}$ were used as negative and positive controls, respectively. This control peptide was the C-terminal sequence (29-43) of salivary statherin, which showed no antimicrobial properties in our previous studies (data not shown).

Bactericidal assay. The bactericidal assay was performed according to procedures described by Miyasaki et al. (1997, 1998) with a slight modification. Briefly, bacterial suspension in Hanks' balanced salt solution (HBSS; Sigma), $\mathrm{pH} 7 \cdot 0$, or in $0.01 \%$ BHI (Actinobacillus actinomycetemcomitans), was adjusted spectrophotometrically at $660 \mathrm{~nm}$ to approximately $1 \cdot 0 \times 10^{7}$ cells $\mathrm{ml}^{-1}$. Bacterial suspension $(90 \mu \mathrm{l})$ was mixed with $10 \mu \mathrm{KSL}$ at different concentrations and the reactions were incubated at $37^{\circ} \mathrm{C}$ for $15 \mathrm{~min}$. The reaction was terminated by adding $900 \mu \mathrm{l}$ ice-cold HBSS to the mixture and $50 \mu \mathrm{l}$ of each sample was spiral-plated on agar media, as specified in the Results section. Susceptibility was determined by examining the log reduction in viability counts of organisms that had been exposed to different concentrations of KSL. Bacteria suspended in HBSS served as a control. Bactericidal activity was also expressed as the $99 \%$ effective dose $\left(\mathrm{ED}_{99}\right)$, which is the concentration of the antimicrobial decapeptide at which there is a $2-\log$ or more reduction in c.f.u. Four strains, $S$. mutans ATCC $25175^{\mathrm{T}}$, S. gordonii ATCC 51656, Actinobacillus actino- mycetemcomitans ATCC 43718 and L. salivarius ATCC 29602, were tested for their susceptibility to KSL by the bactericidal assay.

In vitro killing of saliva bacteria. The killing assay of saliva bacteria was done according to procedures established by Helmerhorst et al. (1999) with a slight modification. Unstimulated saliva was collected from four healthy individuals who had refrained from eating for at least $2 \mathrm{~h}$. The study was approved by the Institutional Review Board of the Walter Reed Army Institute of Research and informed consent and sample donation consent were obtained from all volunteers. Pooled saliva was initially spun at 500 r.p.m. in an Eppendorf centrifuge (model 5810R) for $10 \mathrm{~min}$ at $4{ }^{\circ} \mathrm{C}$ to remove epithelial cells and mucus. Saliva bacteria were collected by spinning the supernatant at 4000 r.p.m. for $15 \mathrm{~min}$ at $4{ }^{\circ} \mathrm{C}$. The pellet was washed three times in $10 \mathrm{mM}$ potassium phosphate buffer (PPB) and suspended in the same buffer to give approximately $1 \cdot 0 \times 10^{7}$ cells $\mathrm{ml}^{-1}$. Bacterial suspension $(250 \mu \mathrm{l})$ was mixed with $250 \mu$ peptide to obtain final peptide concentrations of $12 \cdot 5$, $25,50,100$ and $200 \mu \mathrm{g} \mathrm{ml}^{-1}$. After incubation of the mixture at $37^{\circ} \mathrm{C}$ for $30 \mathrm{~min}$, cells were spun down to remove KSL, washed once in PBS ( $\mathrm{pH}$ 7.4) and suspended in PBS before spiral-plating $(50 \mu \mathrm{l})$ of the treated and untreated (negative control; exposed to buffer only) cells in different dilutions on BAP. Saliva bacteria exposed to $0 \cdot 12 \%$ aqueous chlorhexidine served as positive controls.

\section{Assessing viability of KSL-treated saliva bacteria. A LIVE/DEAD} BacLight Bacterial Viability kit (Molecular Probes) was used to assess the viability and status of membrane integrity in saliva bacteria treated with aqueous KSL $\left(200 \mu \mathrm{g} \mathrm{ml}^{-1}\right)$. BacLight assay solution was prepared as described by the manufacturer. Saliva bacterial suspension in PPB (50 $\mu \mathrm{l}$ ) was mixed with an equal volume of aqueous KSL to obtain a final peptide concentration of $200 \mu \mathrm{g} \mathrm{ml}^{-1}$. Bacterial suspension mixed with sterile $\mathrm{dH}_{2} \mathrm{O}$ was used as the negative control. BacLight solution $(1.5 \mu \mathrm{l})$ was added to the mixture after incubation at $37^{\circ} \mathrm{C}$ for $30 \mathrm{~min}$. The reaction mixture was incubated further at room temperature in the dark for $15 \mathrm{~min}$. Samples were observed by using a fluorescence Axioplan 2 imaging system (Zeiss) equipped with longpass and dual-emission filters (Chroma) for simultaneous viewing of live (stained by SYTO 9) and dead (stained by propidium iodide) bacteria.

In vitro toxicity studies. HGF, obtained from the ATCC (Manassas, VA, USA), were used as the target for in vitro toxicity studies. HGF were cultured in RPMI 1640 medium (GibcoBRL) that contained $5 \%$ fetal bovine serum at $37^{\circ} \mathrm{C}$ in a $\mathrm{CO}_{2}$ incubator prior to exposure to various concentrations of KSL, which included concentrations that were at least tenfold (up to $1 \mathrm{mg} \mathrm{ml}^{-1}$ ) above the effective antimicrobial doses used in the bactericidal assay. Cells that were exposed to medium alone served as controls. Untreated and affected cells were examined for viability, as determined by their ability to reduce 3-(4,5-dimethylthiazol-2-yl)-2,5diphenyltetrazolium bromide (MTT) (Sigma) (Mosmann, 1983), and their membrane integrity, as a function of the amount of cytoplasmic lactate dehydrogenase $(\mathrm{LDH})$ released into the medium (Decker \& Lohmann-Matthes, 1988). Detection of cellular conversion of MTT to water-insoluble coloured formazan and determination of total (cytoplasmic and extracellular) and extracellular LDH of affected and untreated cells were done according to the instructions of the manufacturer of a commercially available in vitro toxicity assay kit (Sigma). Reaction products of the LDH assay were measured spectrophotometrically by using a test wavelength of $490 \mathrm{~nm}$ and a reference wavelength of $690 \mathrm{~nm}$. For measuring acid/isopropanol-solubilized formazan, a test wavelength of $570 \mathrm{~nm}$ and a reference wavelength of $630 \mathrm{~nm}$ were used. 


\section{RESULTS}

\section{Synthesis of peptide}

KSL, synthesized by using standard Fmoc chemistry, was purified by reverse-phase HPLC and subjected to MALDITOF MS to verify the integrity of the peptide. The mass spectrum of KSL had an intense molecular ion at $\mathrm{m} / \mathrm{z}$ $1249 \cdot 80$, which was consistent with its relative molecular mass of 1250 (data not shown).

\section{NMR studies of KSL}

Sequential resonance assignments of KSL. Assignments of ${ }^{1} \mathrm{H}$ resonances were accomplished by combined analyses of 2D TOCSY and 2D NOE spectra. Identification of most of the spin systems was achieved unambiguously from amide proton-relayed TOCSY connectivities. Assignment of resonances to individual amino acids was accomplished by combined analyses of the $\mathrm{NH}-\mathrm{C}_{\alpha} \mathrm{H}$ connectivities in the fingerprint regions in the TOCSY and 2D NOE spectra, as described previously (Raj et al., 1996, 1998, 2000a).

Conformational analysis in aqueous solution. A summary of observed NOE connectivities, temperature coefficients of $\mathrm{NH}$ chemical shifts and coupling constant $\left(J_{\mathrm{NH}-\mathrm{C}^{\alpha} \mathrm{H}}\right)$ values are provided in Fig. 1. Temperature coefficients of all amide resonances provided in Fig. 1(a) are high ( $\geqslant 0.0042$ p.p.m. $\mathrm{K}^{-1}$ ) and the fast ${ }^{1} \mathrm{H} /{ }^{2} \mathrm{H}$ exchange rate observed for all backbone amide resonances (Fig. 1a) in $65 \%{ }^{2} \mathrm{H}_{2} \mathrm{O}$ provides evidence that the amide groups are not involved in any intramolecular hydrogen bonding. Prevalence of strong $\alpha \mathrm{N}$ $(i, i+1)$ and weak $\alpha \mathrm{N}(i, i)$ NOEs (Fig. 1a) and a continuous stretch of weak and medium $\beta \mathrm{N}(i, i)$ and $\alpha \beta(i, i)$ NOEs (Fig. 1a) in the absence of any observable NN NOE interactions indicate that the backbone dihedral angles are predominantly in the unfolded extended region of the $\phi, \psi$ space (Wüthrich, 1986). The $J_{\mathrm{NH}-\mathrm{C}^{\alpha} \mathrm{H}}$ values provided in Fig. 1a are $\geqslant 7 \cdot 3 \mathrm{~Hz}$ for all residues except Lys 2 and Phe9. Coupling constants of 7·3$8 \cdot 1 \mathrm{~Hz}$ were observed for most residues of KSL; this suggests the existence of populations of unfolded, non-hydrogenbonded conformations of comparable energy with $\phi$ values that exceed those of the regular helical region. The NMR data obtained provide evidence that KSL molecules remain unstructured in aqueous solution.

Conformational analysis in DMSO solution. In $\left(\mathrm{C}^{2} \mathrm{H}_{3}\right)_{2} \mathrm{SO}$, lowered temperature coefficients of backbone amide groups $\left(\leqslant 0 \cdot 0029\right.$ p.p.m. $\mathrm{K}^{-1}$ ), except for the first four residues, have been observed (Fig. 1b). These results suggest that six amide $\mathrm{NH}$ groups from Phe5 to Lys10 could be involved in intramolecular hydrogen bonding, whereas the amide $\mathrm{NH}$ groups of Lys2, $\mathrm{Val} 3$ and $\mathrm{Val} 4$ are well exposed to the solvent. Slow ${ }^{1} \mathrm{H} /{ }^{2} \mathrm{H}$ exchange of the Phe5-Lys10 NH groups (Fig. 1b) also suggests that the amide NHs of Phe5-Lys10 may be inaccessible to the solvent and are probably involved in intramolecular hydrogen bonds (Wüthrich, 1986). In $\left(\mathrm{C}^{2} \mathrm{H}_{3}\right)_{2} \mathrm{SO}$, the $J_{\mathrm{NH}-\mathrm{C}^{\alpha} \mathrm{H}}$ values were in the range $5 \cdot 2-5 \cdot 9$ (a)

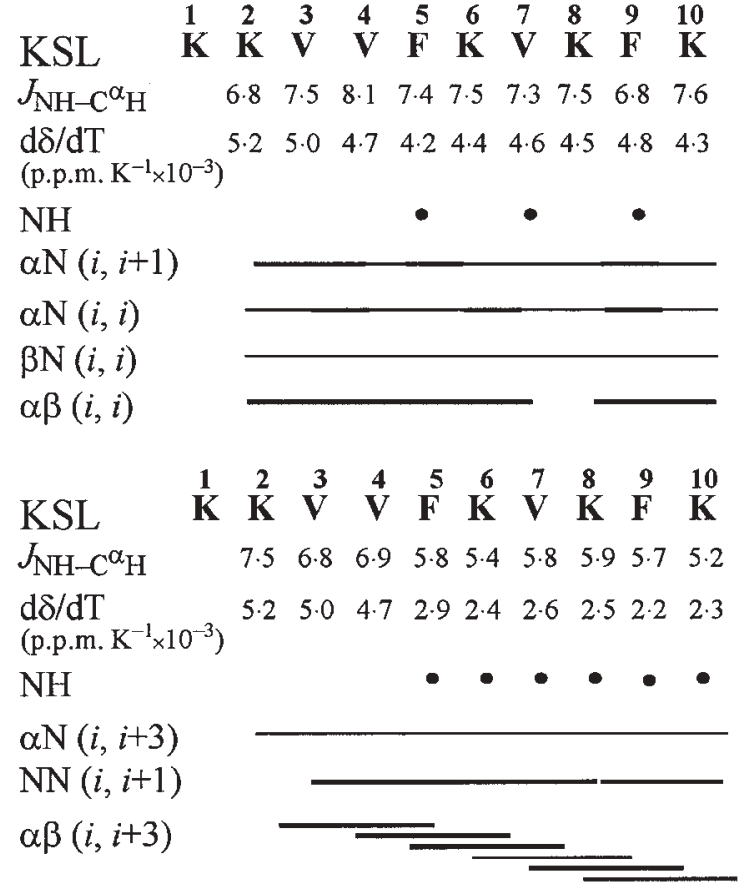

Fig. 1. Summary of sequential and medium-range NOE data compiled from the NOESY spectra of $\mathrm{KSL}$ recorded at $30{ }^{\circ} \mathrm{C}$ : (a) in $\mathrm{H}_{2} \mathrm{O}$ / ${ }^{2} \mathrm{H}_{2} \mathrm{O}$, using a mixing time of $150 \mathrm{~ms}$; and (b) in $\left(\mathrm{C}^{2} \mathrm{H}_{3}\right)_{2} \mathrm{SO}$, using a mixing time of $200 \mathrm{~ms}$. Thickness of bars indicates that the NOE is strong, medium and weak, respectively. $\bullet$ Slow-exchanging amide $\mathrm{NHs}$.

$\mathrm{Hz}$ for residues from Phe5 to Lys10 (Fig. 1b), indicating the presence of a significant population of helical conformation in DMSO solution. The summary of sequential and mediumrange NOEs observed for KSL (Fig. 1b) in $\left(\mathrm{C}^{2} \mathrm{H}_{3}\right)_{2} \mathrm{SO}$ shows sequential $\mathrm{NN}(i, i+1)$ connectivities and medium-range $\alpha \beta$ $(i, i+3)$ interactions that are characteristic of $\alpha$-helical conformations (Wüthrich, 1986; Dyson \& Wright, 1991). In addition, a complete set of weak $\alpha \mathrm{N}(i, i+3)$ NOEs, expected for $\alpha$-helical conformation, was observed (Fig. 1b). These NOE NN $(i, i+1)$ values provide support for the prevalence of a threshold population of $\alpha$-helical conformations. Collectively, the NMR data suggest strongly that KSL exists as $\alpha$-helical conformers that involve Lys2-Lys10, which are stabilized by six $(5 \rightarrow 1)$ intramolecular hydrogen bonds in $\left(\mathrm{C}^{2} \mathrm{H}_{3}\right)_{2} \mathrm{SO}$.

Molecular structure of KSL in DMSO solution. The average structure of a family of 16 conformers obtained after energy minimization of the distance geometry algorithm for NMR applications (DIANA) structures, as described in the Methods section, is shown in Fig. 2(left). A view of the $\alpha$-helical structure along the helix axis is also provided in Fig. 2 (right). The calculated mean pairwise root mean square deviation (RMSD) and the associated SDs are $1 \cdot 78(0 \cdot 32) \AA$ for all atoms and $1 \cdot 12(0 \cdot 18) \AA$ for the backbone (without taking into consideration the $\mathrm{N}$-terminal residue, Lys1). When taking all 

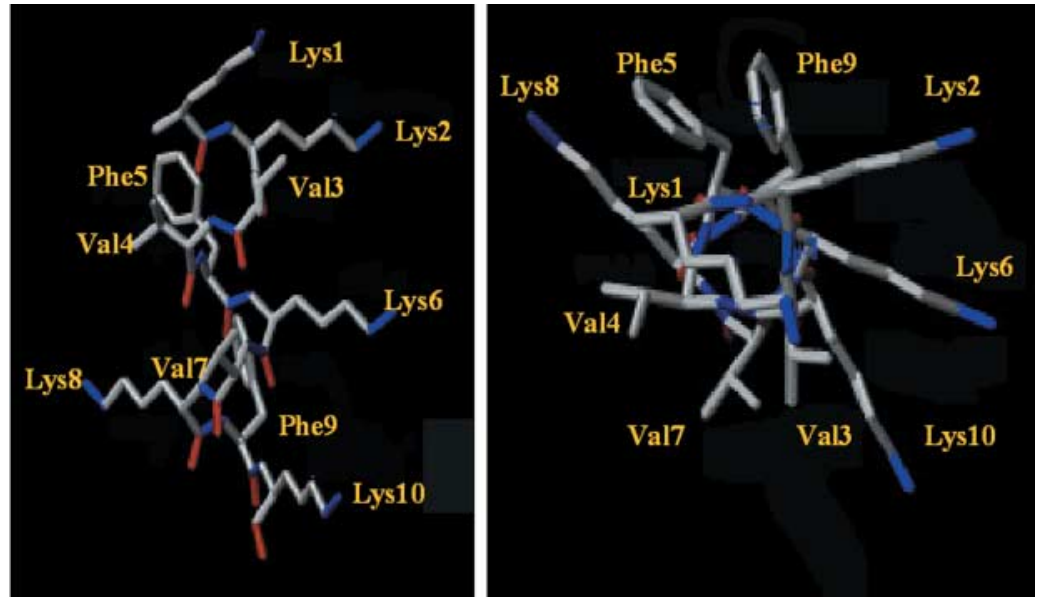

Fig. 2. A perspective view of the averaged $\alpha$ helical structure of KSL with the N-terminus at the top and the C-terminus at the bottom (left). A view of the $\alpha$-helical structure of KSL along the helix axis, illustrating the weak amphipathic nature of the molecule (right). For clarity, hydrogen atoms are not included.

residues into account, RMSDs are 2.38 (0.47) and 1.57 (0.26) $\AA$ for all atoms and backbone atoms, respectively. The structure of KSL is a single-stranded, $\alpha$-helix stabilized by six intramolecular $(5 \rightarrow 1)$ hydrogen bonds formed by the backbone amide NH groups of Phe5-Lys10.

\section{In vitro susceptibility of oral bacteria}

MICs and MBCs of KSL for the majority of oral bacteria tested in MHB or other modified broth were determined (Table 1). MICs ranged from $3 \cdot 13$ to $100 \mu \mathrm{g} \mathrm{ml}^{-1}$ for most of the facultatively anaerobic oral organisms tested. By contrast, the control peptide at $200 \mu \mathrm{g} \mathrm{ml}^{-1}$ did not inhibit the growth of any organisms tested. Bacteria grown in medium that contained the control peptide grew to the same extent as organisms grown in medium alone (data not shown). KSL was effective in inhibiting growth of most of the primary colonizers involved in the initiation of plaque formation, which included Actinomyces naeslundii, S. gordonii and $S$. sanguinis, as demonstrated by the broth microdilution assay. Growth of the cariogenic bacteria S. mutans ATCC $25175^{\mathrm{T}}, \mathrm{S}$. sobrinus and L. acidophilus was also inhibited effectively by

Table 1. In vitro susceptibility of oral bacteria to KSL

\begin{tabular}{|c|c|c|}
\hline Bacterial strain ${ }^{\star}$ & $\operatorname{MIC}\left(\mu \mathrm{g} \mathrm{ml}^{-1}\right) \dagger$ & $\operatorname{MBC}\left(\mu \mathrm{g} \mathrm{ml}^{-1}\right)$ \\
\hline Actinomyces naeslundii T14V-J1 & $3 \cdot 13$ & $12 \cdot 5$ \\
\hline Actinomyces israelii ATCC 10049 & $6 \cdot 25$ & $12 \cdot 5$ \\
\hline \multicolumn{3}{|l|}{ S. mutans: } \\
\hline ATCC $25175^{\mathrm{T}}$ & $6 \cdot 25$ & $12 \cdot 5$ \\
\hline LT11 & 25 & 100 \\
\hline \multicolumn{3}{|l|}{ S. gordonii: } \\
\hline ATCC 51656 & 50 & 100 \\
\hline DL1 & 50 & 100 \\
\hline \multicolumn{3}{|l|}{ S. sanguinis: } \\
\hline ATCC $10556^{\mathrm{T}}$ & 25 & 100 \\
\hline SK36 & 25 & 50 \\
\hline S. oralis ATCC $35037^{\mathrm{T}}$ & 100 & 200 \\
\hline S. sobrinus ATCC $33478^{\mathrm{T}}$ & 25 & 50 \\
\hline S. salivarius ATCC 9222 & 50 & 100 \\
\hline S. mitis ATCC 15913 & 25 & 50 \\
\hline Actinobacillus actinomycetemcomitans ATCC 43718 & 100 & 200 \\
\hline L. salivarius ATCC 29602 & $3 \cdot 13$ & $12 \cdot 5$ \\
\hline L. acidophilus ATCC $4357^{\circledR}$ & $3 \cdot 13$ & $12 \cdot 5$ \\
\hline
\end{tabular}

*The number of cells used in these assays was $4 \times 10^{6} \mathrm{ml}^{-1}$, with the exception of Actinobacillus and $S$.

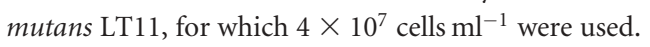

$\dagger \mathrm{MHB}$ was used for the determination of most of the MICs. For S. mitis and Actinobacillus, BHI and 50\% BHI were used as the assay medium, respectively. 10\% MRS and 20\% Actinomyces broth were used as the assay medium for Lactobacillus strains and Actinomyces israelii, respectively. Culture conditions were the same as those described in Methods. 
$\mathrm{KSL}$ at concentrations of $<25 \mu \mathrm{g} \mathrm{ml}^{-1}$. On the other hand, KSL possessed less growth-inhibitory activity against Actinobacillus actinomycetemcomitans and $S$. oralis. In general, many of the MBCs of KSL for the organisms tested were within one to two dilutions of the MICs.

\section{Bactericidal assay (reduction of viable counts)}

In addition to the determinations of MICs and MBCs of KSL, log reductions in viable counts of selected oral bacteria caused by KSL were also determined. These were compared to c.f.u. of organisms incubated in buffer, which served as controls (shown as $0 \mu \mathrm{gSL} \mathrm{ml}^{-1}$ in Fig. 3). With the exception of Actinobacillus actinomycetemcomitans, for which the assays were performed in $0.01 \% \mathrm{BHI}$, bactericidal action of KSL was determined in isotonic HBSS after incubation with the targeted bacteria for $1 \mathrm{~h}$ at $37^{\circ} \mathrm{C}$. KSL at $6.25 \mu \mathrm{g} \mathrm{ml}^{-1}$, which was determined to be the $99 \%$ effective dose (ED99), caused more than 2 log reductions in viable counts of the organisms tested, which included $L$. salivarius ATCC 29602, S. mutans ATCC $25175^{\mathrm{T}}$, S. gordonii ATCC 51656 and Actinobacillus actinomycetemcomitans ATCC 43718 (Fig. 3).

\section{Viability and membrane integrity of saliva bacteria treated with KSL}

There was a significant reduction in viable counts of facultatively anaerobic oral bacteria collected from saliva with exposure to increasing concentrations of KSL (Fig. 4).
Treatment of the saliva bacteria with a final concentration of $200 \mu \mathrm{g} \mathrm{KSL} \mathrm{ml}{ }^{-1}$ resulted in a $1 \cdot 05-\log$ reduction in facultative anaerobes that were present in the saliva, compared to PBS-treated saliva samples (negative control). As a positive control, chlorhexidine $(0.12 \%)$ caused a $>3$-log reduction in facultatively anaerobic saliva organisms (data not shown).

Fluorescence microscopy of samples stained with LIVE/ DEAD BacLight assay solution showed that many of the saliva bacteria in the control sample (bacteria treated with $\mathrm{dH}_{2} \mathrm{O}$ ) fluoresced green (Fig. 5a). On the other hand, bacterial suspension that had been treated with KSL showed a significant number of saliva bacteria that fluoresced red (Fig. 5b)

\section{Viability of KSL-treated HGF}

KSL at concentrations up to $1 \mathrm{mg} \mathrm{ml}^{-1}$ did not induce cell death of KSL-treated fibroblasts, as indicated by the ability of treated cells to reduce MTT at levels that were similar to those of untreated HGF (Fig. 6a). Also, KSL did not compromise the membrane integrity of KSL-treated fibroblasts. Similar levels of extracellular LDH were observed among KSLtreated cells and untreated HGF (Fig. 6b). HGF contained a significant amount of intracellular $\mathrm{LDH}$, as indicated by the amount of total LDH recovered from lysed, untreated HGF (Fig. 6b). (a) L salivarius ATCC 29602

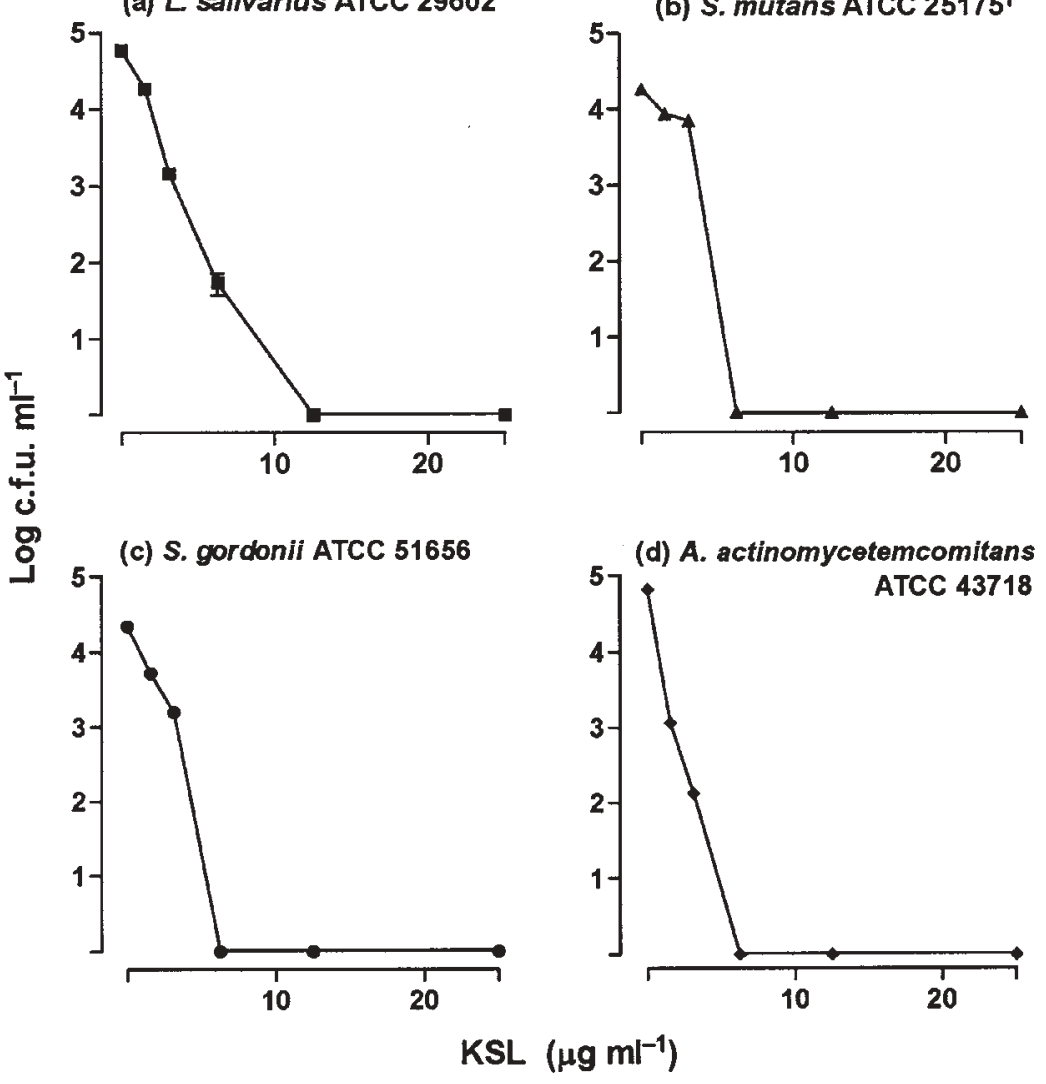

Fig. 3. Killing of: (a) L. salivarius ATCC 29602; (b) S. mutans ATCC $25175^{\top}$; (c) S. gordonii ATCC 51656; and (d) Actinobacillus actinomycetemcomitans ATCC 43718 by KSL. Killing assays were done in HBSS with the exception of Actinobacillus actinomycetemcomitans, which was assayed in 0.01\% BHI. Points and vertical lines represent the mean and SD of quadruplicate determinations. The data represent the results of one of the three separate experiments performed. 


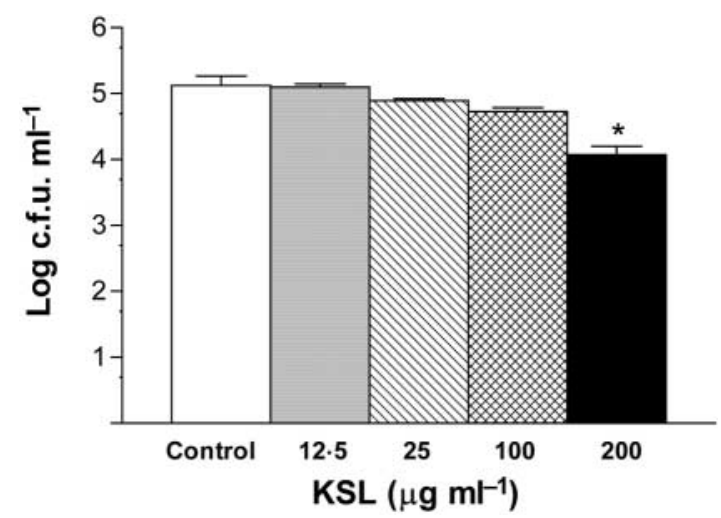

Fig. 4. Log reductions in c.f.u. of facultatively anaerobic bacteria collected from saliva after incubation for $30 \mathrm{~min}$ at $37^{\circ} \mathrm{C}$ in $10 \mathrm{mM}$ PPB with or without KSL (control, $\mathrm{dH}_{2} \mathrm{O}$ ). A Mann-Whitney test was used for comparison of the experimental groups with the control group. The asterisk represents statistical significance from control $(P<0.05)$. The data represent the results of one of the three separate experiments, each performed in quadruplicate. Bars, SD.

\section{DISCUSSION}

In this study, we tested the growth-inhibitory activity of KSL, a cationic decapeptide that was identified by synthetic combinatorial library technology (Hong et al., 1998). We have demonstrated that this peptide: (i) was effective in inhibiting the growth of a broad range of laboratory strains of oral bacteria; (ii) at higher concentrations, was capable of reducing viable counts of members of resident saliva bacteria collected from healthy human subjects; and (iii) did not show any cytotoxic effects against HGF.

For most oral bacteria tested, effective killing doses of KSL in vitro are comparable to those of other antimicrobial peptides, which include human defensins (Miyasaki et al., 1990; Raj et al., 2000b), rabbit bactenecins (Raj et al., 2000a), human salivary histatins (Helmerhorst et al., 1997, 1999; MacKay et al., 1984) and porcine protegrins (Miyasaki et al., 1997, 1998; Mosca et al., 2000). Our studies showed that KSL was effective against many oral pathogens. For example, growth of Actinomyces naeslundii, a putative pathogen that is involved in the development of gingivitis (Loesche \& Syed, 1978) and root-surface caries (Summey \& Jordan, 1974) and is an early colonizer for plaque formation (Kolenbrander et al., 1993; Gibbons, 1996) was inhibited by KSL at a fairly low concentration, i.e. $3 \cdot 13 \mu \mathrm{g} \mathrm{ml}^{-1}$. Similarly, growth of $S$. mutans ATCC $25175^{\mathrm{T}}$ and L. acidophilus, cariogenic organisms (Bowden, 1991; van Houte, 1994), was inhibited by KSL at concentrations of $<10 \mu \mathrm{g} \mathrm{ml}^{-1}$.

In this study, growth of $S$. oralis [a member of the $S$. oralis group (Kilian et al., 1989)] and Actinobacillus actinomycetemcomitans appeared to be less affected by KSL in our susceptibility assay. At present, we do not know what factors may contribute to variation of susceptibility among different strains of oral bacteria tested. However, it is known that
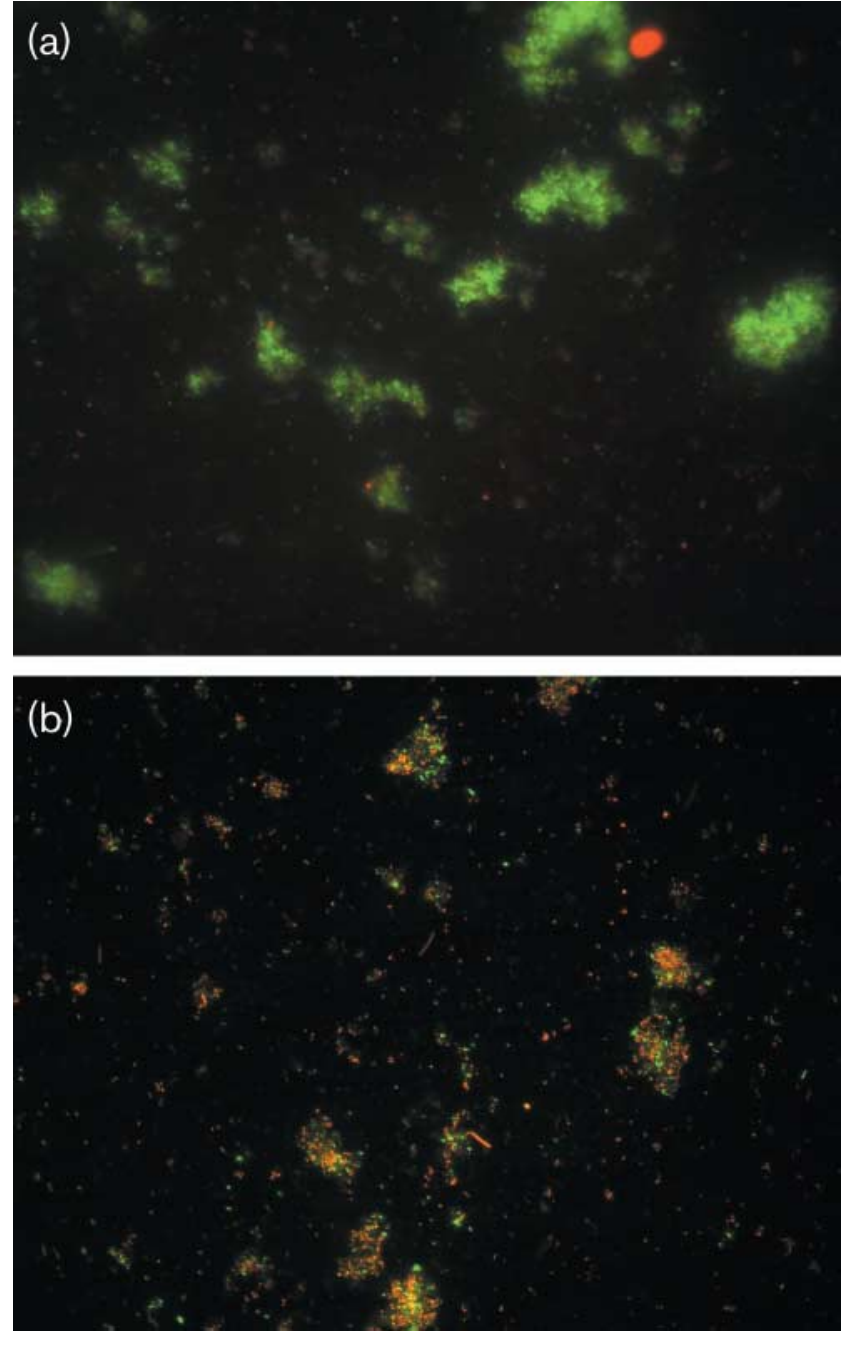

Fig. 5. LIVE/DEAD BacLight staining of saliva bacteria treated with (a) $\mathrm{dH}_{2} \mathrm{O}$ (control) or (b) KSL. Many of the isolated bacteria appear in aggregates of various sizes. Note: many bacteria in the control sample stained green (live), whereas a significant number of bacteria in the KSL-treated sample stained red (dead). The bright red oval structure, located near the top on the right of the image for the control sample, represents the nucleus of a dead buccal epithelial cell. Magnification, $400 \times$.

bacterial species exhibit a wide range of susceptibilities to antimicrobial peptides (Boman, 1991; Zasloff, 2002). The basis for the difference in susceptibilities of bacterial species against particular peptides is not known at present (Zasloff, 2002).

By contrast, growth of other members of the $S$. oralis group, S. sanguinis, S. gordonii and S. mitis, was inhibited by KSL, with MICs that ranged from 25 to $50 \mu \mathrm{g} \mathrm{ml}^{-1}$. Members of the $S$. oralis group, together with Actinomyces naeslundii as described above, are primary colonizers of the cleaned tooth and can undergo intra- and intergeneric co-aggregation with a range of partner organisms in vivo, which contributes to 

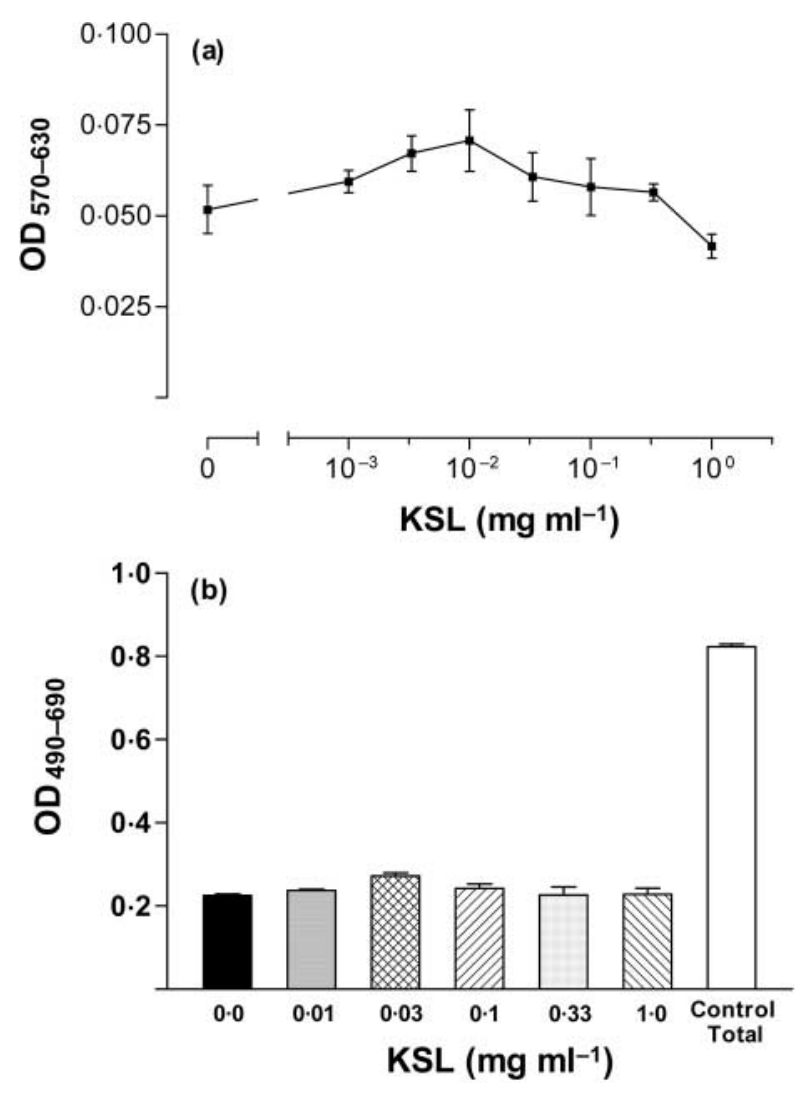

Fig. 6. Determination of reduction of (a) MTT and (b) LDH release by KSL-treated or untreated fibroblasts. Points and bars represent the mean and SD of triplicate determinations. Two thousand five hundred and ten thousand fibroblasts were used in each determination of LDH release and MTT reduction, respectively. Cells were cultured for $72 \mathrm{~h}$ at $37{ }^{\circ} \mathrm{C}$ in a $\mathrm{CO}_{2}$ incubator before exposure to different concentrations of KSL. HGF were exposed to KSL for $6 \mathrm{~h}$ prior to measurements. The data represent the results of one of the two separate experiments.

plaque accumulation (Kolenbrander \& London, 1992). The observation that KSL at $50 \mu \mathrm{g} \mathrm{ml}^{-1}$ or below was inhibitory in vitro to growth of most members of the $S$. oralis group, Actinomyces naeslundii and the major cariogenic pathogens suggests that KSL could be effective in controlling the formation of plaque and dental caries in vivo. This is supported by the observation that KSL, at higher concentrations, caused significant reductions in viable counts of resident saliva bacteria. This is particularly relevant as saliva bacteria are released from biofilms formed on hard and soft tissues in the oral cavity (Helmerhorst et al., 1999). Furthermore, it has been shown that these bacteria or bacteria collected from plaque are more resistant to antimicrobial peptides than pure cultures of oral bacteria (Helmerhorst et al., 1999). This may be one of the reasons why higher concentrations of antimicrobials are needed to inhibit the growth of resident saliva bacteria, as also shown in this study.
In addition to the determination of MICs and MBCs of KSL against oral bacteria, we also performed a bactericidal assay, i.e. $\log$ reductions in viable counts, to obtain $\mathrm{ED}_{99}$ values of KSL on selected organisms. These oral bacteria, which included L. salivarius, S. mutans, S. gordonii and Actinobacillus actinomycetemcomitans, showed significant reductions in viability ( $>3$ logs) when exposed to KSL at concentrations of $<10 \mu \mathrm{g} \mathrm{ml}^{-1}$. With the exception of Actinobacillus actinomycetemcomitans [a causative agent for juvenile periodontitis (Slots et al., 1986)] and S. gordonii, our observations generally supported the MICs that were determined for these selected organisms. Interestingly, whilst KSL was less effective in inhibiting the growth of Actinobacillus actinomycetemcomitans and S. gordonii, as shown by the broth microdilution assay for MIC determinations, the peptide showed more potent inhibitory activity against the growth of these organisms in the bactericidal assay. These discrepancies could be attributable to the salinity of assay media used for determining the MICs and $\mathrm{ED}_{99}$ of KSL, as indicated by a number of earlier reports on in vitro bactericidal activity of antimicrobial peptides (Lee et al., 1997; Friedrich et al., 1999; Tanaka et al., 2000; Guthmiller et al., 2001; Murakami et al., 2002; Zasloff, 2002).

In this study, we were also interested in establishing the conformation of KSL in membrane environments. The three-dimensional structure of this antimicrobial peptide has not been reported previously, although the secondary structure of this peptide was predicted by circular dichroism (CD). Previous CD data suggested an $\alpha$-helical conformation for KSL in the presence of $50 \%$ trifluoroethanol and a distorted $\alpha$-helical structure in the presence of $25 \mathrm{mM}$ SDS (Oh et al., 1999). However, determination of the helicity of small oligopeptides based on absolute mean ellipticity values often leads to ambiguous secondary structure prediction (Raj et al., 1990). Moreover, the conformational features of each individual residue in the sequence of the peptide cannot be ascertained and a clear distinction between $\alpha$-and $3_{10}$-helical structures cannot be made by $\mathrm{CD}$ data. Hence, we determined the three-dimensional structure of KSL both in aqueous solution and in DMSO, which mimics the polar aprotic membrane environment. NMR data indicate that this peptide remains largely in its $\alpha$-helical conformation (Fig. 2) in membrane environments, whilst it prefers to adopt an unfolded random structure in aqueous solution.

The view of the helical structure of KSL along the helix axis (Fig. 2) does not reflect a perfect amphiphilic structure. Enhancing amphiphilicity by the substitution of Lys 1 and Lys8 by Leu residues has been reported to increase the helicity. However, antimicrobial activity has been found to decrease (Oh et al., 1999), thereby indicating the importance of cationic residues and the weak amphiphilicity of KSL. The weak amphiphilic nature of KSL indicates that its spontaneous insertion into microbial membranes and formation of ion channels across cell membranes is unlikely. This weak amphiphilicity probably accounts for the minimal toxicity to mammalian cells observed for KSL. This peptide is polar and hydrophilic, suggesting that the mechanism of its antimi- 
crobial action could primarily involve electrostatic (ionic type), hydrogen bonding and hydrophobic interactions with the polar face of microbial membranes or with a membranebound receptor molecule, leading to possible membrane damage.

Furthermore, in the initial characterization of this novel antimicrobial peptide, Hong et al. (1998) suggested that this decapeptide may kill micro-organisms by attacking their membranes, as extrapolated from their work performed with artificial membranes. By using a BacLight Viability kit, we demonstrated that KSL could cause actual membrane damage to bacteria. This was illustrated by the presence of a significant number of organisms that fluoresced red in the KSL-treated saliva bacteria sample. SYTO 9, which is present in the assay solution, can enter all cells and fluoresces green. On the other hand, propidium iodide, which fluoresces red and is present as the second stain in the assay solution, is excluded from cells with intact membranes. However, propidium iodide is able to enter cells with a damaged membrane and competes with and quenches SYTO 9 for labelling the DNA, to make such cells fluoresce red (Lisle et al., 1999). The staining reactions of the bacteria that we observed provide strong morphological evidence to suggest that the membranes of KSL-treated bacteria were compromised, whereas membranes of bacteria exposed to $\mathrm{dH}_{2} \mathrm{O}$ remained intact, as illustrated by the presence of many green fluorescent bacteria in this sample.

An earlier study showed that KSL is non-toxic to mammalian cells, as demonstrated by its lack of haemolytic activity against mouse erythrocytes (Hong et al., 1998). In this study, we confirmed and extended the in vitro toxicity study to include testing of KSL against HGF. Our data indicated strongly that KSL neither induced cell death nor compromised the membrane integrity of HGF that were exposed to an up to tenfold excess of effective bactericidal dosages of this peptide. Similarly to other antimicrobial peptides (Hancock, 1997b; Zasloff, 2002), the results suggest that KSL specifically targets the membrane of prokaryotes, but not that of mammalian cells.

In this study, we have focused on the effects of KSL on cariogenic organisms and primary colonizers that are involved in the early development of dental plaque. Another important step towards the establishment of KSL as a potential antiplaque agent is to test, in future studies, the effectiveness of KSL against subgingival plaque bacteria, which are primarily obligate anaerobes and consist of organisms that are involved in the development of periodontal diseases (Socransky, 1998).

\section{ACKNOWLEDGEMENTS}

This work was supported by the US Army Medical Research and Materiel Command. The views expressed in this article are those of the authors and do not reflect the official policy or position of the Department of the Army, the Department of Defense or the US Government.

\section{REFERENCES}

Bateman, A., Singh, A., Shustik, C., Mars, W. M. \& Solomon, S. (1991). The isolation and identification of multiple forms of the neutrophil granule peptides from human leukemic cells. J Biol Chem 266, 7524-7530.

Blondelle, S. E. \& Houghten, R. A. (1996). Novel antimicrobial compounds identified using synthetic combinatorial library technology. Trends Biotechnol 14, 60-65.

Blondelle, S. E., Takahashi, E., Weber, P. A. \& Houghten, R. A. (1994). Identification of antimicrobial peptides by using combinatorial libraries made up of unnatural amino acids. Antimicrob Agents Chemother 38, 2280-2286.

Blondelle, S. E., Pérez-Payá, E. \& Houghten, R. A. (1996a). Synthetic combinatorial libraries: novel discovery strategy for identification of antimicrobial agents. Antimicrob Agents Chemother 40, 1067-1071.

Blondelle, S. E., Takahashi, E., Houghten, R. A. \& Pérez-Payá, E. (1996b). Rapid identification of compounds with enhanced antimicrobial activity by using conformationally defined combinatorial libraries. Biochem J 313, 141-147.

Boggiano, C., Reixach, N., Pinilla, C. \& Blondelle, S. E. (2003). Successful identification of novel agents to control infectious diseases from screening mixture-based peptide combinatorial libraries in complex cell-based bioassays. Biopolymers 71, 103-116.

Boman, H. G. (1991). Antibacterial peptides: key components needed in immunity. Cell 65, 205-207.

Boman, H. G. (1998). Gene-encoded peptide antibiotics and the concept of innate immunity: an update review. Scand J Immunol $\mathbf{4 8}$, $15-25$.

Bowden, G. H. W. (1991). Which bacteria are cariogenic in humans? In Risk Markers for Oral Diseases, vol. 1, pp. 266-286. Edited by N. W. Johnson. Cambridge, UK: Cambridge University Press.

Chen, J., Falla, T. J., Liu, H. \& 9 other authors (2000). Development of protegrins for the treatment and prevention of oral mucositis: structureactivity relationships of synthetic protegrin analogues. Biopolymers $\mathbf{5 5}$, $88-98$.

Davies, J. (1994). Inactivation of antibiotics and the dissemination of resistance genes. Science 264, 375-382.

Decker, T. \& Lohmann-Matthes, M. L. (1988). A quick and simple method for the quantitation of lactate dehydrogenase release in measurements of cellular cytotoxicity and tumor necrosis factor (TNF) activity. J Immunol Methods 115, 61-69.

Dyson, H. J. \& Wright, P. E. (1991). Defining solution conformations of small linear peptides. Annu Rev Biophys Biophys Chem 20, 519-538.

Elsbach, P. (2003). What is the real role of antimicrobial polypeptides that can mediate several other inflammatory responses? J Clin Invest 111, 1643-1645.

Friedrich, C., Scott, M. G., Karunaratne, N., Yan, H. \& Hancock, R. E. W. (1999). Salt-resistant alpha-helical cationic antimicrobial peptides. Antimicrob Agents Chemother 43, 1542-1548.

Fuchs, P. C., Barry, A. L. \& Brown, S. D. (1998). In vitro antimicrobial activity of MSI-78, a magainin analog. Antimicrob Agents Chemother 42, 1213-1216.

Gibbons, R. J. (1996). Role of adhesion in microbial colonization of host tissues: a contribution of oral microbiology. J Dent Res 75, 866-870.

Guthmiller, J. M., Vargas, K. G., Srikantha, R., Schomberg, L. L., Weistroffer, P. L., McCray, P. B., Jr \& Tack, B. F. (2001). Susceptibilities of oral bacteria and yeast to mammalian cathelicidins. Antimicrob Agents Chemother 45, 3216-3219.

Hancock, R. E. W. (1997a). Antibacterial peptides and the outer membranes of Gram-negative bacilli. J Med Microbiol 46, 1-3.

Hancock, R. E. W. (1997b). Peptide antibiotics. Lancet 349, 418-422. 
Hancock, R. E. W. \& Lehrer, R. (1998). Cationic peptides: a new source of antibiotics. Trends Biotechnol 16, 82-88.

Hancock, R. E. W. \& Chapple, D. S. (1999). Peptide antibiotics. Antimicrob Agents Chemother 43, 1317-1323.

Hancock, R. E. W. \& Rozek, A. (2002). Role of membranes in the activities of antimicrobial cationic peptides. FEMS Microbiol Lett 206, 143-149.

Hancock, R. E. W., Falla, T. \& Brown, M. (1995). Cationic bactericidal peptides. Adv Microb Physiol 37, 135-175.

Helmerhorst, E. J., van't Hof, W., Veerman, E. C. I., Simoons-Smit, I. \& Nieuw Amerongen, A. V. (1997). Synthetic histatin analogues with broad-spectrum antimicrobial activity. Biochem J 326, 39-45.

Helmerhorst, E. J., Hodgson, R., van't Hof, W., Veerman, E. C. I., Allison, C. \& Nieuw Amerongen, A. V. (1999). The effects of histatin-derived basic antimicrobial peptides on oral biofilms. J Dent Res 78, 1245-1250.

Henderson, B., Poole, S. \& Wilson, M. (editors) (1998). BacteriaCytokine Interactions in Health and Disease. London: Portland Press.

Hong, S. Y., Oh, J. E., Kwon, M., Choi, M. J., Lee, J. H., Lee, B. L., Moon, H. M. \& Lee, K. H. (1998). Identification and characterization of novel antimicrobial decapeptides generated by combinatorial chemistry. Antimicrob Agents Chemother 42, 2534-2541.

Kaiser, E., Colescott, R. L., Bossinger, C. D. \& Cook, P. I. (1970). Color test for detection of free terminal amino groups in the solid-phase synthesis of peptides. Anal Biochem 34, 595-598.

Kilian, M., Mikkelsen, L. \& Henrichsen, J. (1989). Taxonomic study of viridans streptococci: description of Streptococcus gordonii sp. nov. and emended descriptions of Streptococcus sanguis (White and Niven 1946), Streptococcus oralis (Bridge and Sneath 1982), and Streptococcus mitis (Andrewes and Horder 1906). Int J Syst Bacteriol 39, 471-484.

Koczulla, A. R. \& Bals, R. (2003). Antimicrobial peptides: current status and therapeutic potential. Drugs 63, 389-406.

Koczulla, R., von Degenfeld, G., Kupatt, C. \& 17 other authors (2003). An angiogenic role for the human peptide antibiotic LL-37/hCAP-18. J Clin Invest 111, 1665-1672.

Kolenbrander, P. E. \& London, J. (1992). Ecological significance of coaggregation among oral bacteria. Adv Microb Ecol 12, 183-217.

Kolenbrander, P. E., Ganeshkumar, N., Cassels, F. J. \& Hughes, C. V. (1993). Coaggregation: specific adherence among human oral plaque bacteria. FASEB J 7, 406-413.

Lee, I. H., Cho, Y. \& Lehrer, R. I. (1997). Effects of $\mathrm{pH}$ and salinity on the antimicrobial properties of clavanins. Infect Immun 65, 2898-2903.

Lisle, J. T., Stewart, P. S. \& McFeters, G. A. (1999). Fluorescent probes applied to physiological characterization of bacterial biofilms. Methods Enzymol 310, 166-178.

Loesche, W. J. \& Syed, S. A. (1978). Bacteriology of human experimental gingivitis: effect of plaque and gingivitis score. Infect Immun 21, 830-839.

MacKay, B. J., Denepitiya, L., lacono, V. J., Krost, S. B. \& Pollock, J. J. (1984). Growth-inhibitory and bactericidal effects of human parotid salivary histidine-rich polypeptides on Streptococcus mutans. Infect Immun 44, 695-701.

Mickels, N., McManus, C., Massaro, J. \& 7 other authors (2001). Clinical and microbial evaluation of a histatin-containing mouthrinse in humans with experimental gingivitis. J Clin Periodontol 28, 404-410.

Miyasaki, K. T., Bodeau, A. L., Selsted, M. E., Ganz, T. \& Lehrer, R. I. (1990). Killing of oral, gram-negative, facultative bacteria by the rabbit defensin, NP-1. Oral Microbiol Immunol 5, 315-319.

Miyasaki, K. T., lofel, R. \& Lehrer, R. I. (1997). Sensitivity of periodontal pathogens to the bactericidal activity of synthetic protegrins, antibiotic peptides derived from porcine leukocytes. J Dent Res 76, 1453-1459.
Miyasaki, K. T., lofel, R., Oren, A., Huynh, T. \& Lehrer, R. I. (1998). Killing of Fusobacterium nucleatum, Porphyromonas gingivalis and Prevotella intermedia by protegrins. J Periodont Res 33, 91-98.

Mosca, D. A., Hurst, M. A., So, W., Viajar, B. S. C., Fujii, C. A. \& Falla, T. J. (2000). IB-367, a protegrin peptide with in vitro and in vivo activities against the microflora associated with oral mucositis. Antimicrob Agents Chemother 44, 1803-1808.

Mosmann, T. (1983). Rapid colorimetric assay for cellular growth and survival: application to proliferation and cytotoxicity assays. J Immunol Methods 65, 55-63.

Murakami, M., Ohtake, T., Dorschner, R. A. \& Gallo, R. L. (2002). Cathelicidin antimicrobial peptides are expressed in salivary glands and saliva. J Dent Res 81, 845-850.

Nizet, V., Ohtake, T., Lauth, X. \& 7 other authors (2001). Innate antimicrobial peptide protects the skin from invasive bacterial infection. Nature 414, 454-457.

Oh, J. E., Hong, S. Y. \& Lee, K. H. (1999). Structure-activity relationship study: short antimicrobial peptides. J Pept Res 53, 41-46.

Pardi, A., Billeter, M. \& Wuthrich, K. (1984). Calibration of the angular dependence of the amide proton-C alpha proton coupling constants, 3JHN alpha, in a globular protein. Use of 3JHN alpha for identification of helical secondary structure. J Mol Biol 180, 741-751.

Raj, P. A., Edgerton, M. \& Levine, M. J. (1990). Salivary histatin 5: dependence of sequence, chain length, and helical conformation for candidacidal activity. J Biol Chem 265, 3898-3905.

Raj, P. A., Marcus, E. \& Edgerton, M. (1996). Delineation of an active fragment and poly(L-proline) II conformation for candidacidal activity of bactenecin 5. Biochemistry 35, 4314-4325.

Raj, P. A., Marcus, E. \& Sukumaran, D. K. (1998). Structure of human salivary histatin 5 in aqueous and nonaqueous solutions. Biopolymers 45, 51-67.

Raj, P. A., Karunakaran, T. \& Sukumaran, D. K. (2000a). Synthesis, microbicidal activity, and solution structure of the dodecapeptide from bovine neutrophils. Biopolymers 53, 281-292.

Raj, P. A., Antonyraj, K. J. \& Karunakaran, T. (2000b). Large-scale synthesis and functional elements for the antimicrobial activity of defensins. Biochem J 347, 633-641.

Rothstein, D. M., Spacciapoli, P., Tran, L. T., Xu, T., Roberts, F. D., Dalla Serra, M., Buxton, D. K., Oppenheim, F. G. \& Friden, P. (2001). Anticandida activity is retained in P-113, a 12-amino-acid fragment of histatin 5. Antimicrob Agents Chemother 45, 1367-1373.

Schutze, G. E., Kaplan, S. L. \& Jacobs, R. F. (1994). Resistant Pneumococcus: a worldwide problem. Infection 22, 233-237.

Slots, J., Bragd, L., Wikström, M. \& Dahlén, G. (1986). The occurrence of Actinobacillus actinomycetemcomitans, Bacteroides gingivalis and Bacteroides intermedius in destructive periodontal disease in adults. J Clin Periodontol 13, 570-577.

Socransky, S. S., Haffajee, A. D., Cugini, M. A., Smith, C. \& Kent, R. L., Jr (1998). Microbial complexes in subgingival plaque. J Clin Periodontol $25,134-144$

Summey, D. L. \& Jordan, H. V. (1974). Characterization of bacteria isolated from human root surface carious lesions. J Dent Res 53, $343-351$.

Tamamura, H., Murakami, T., Horiuchi, S. \& 7 other authors (1995). Synthesis of protegrin-related peptides and their antibacterial and antihuman immunodeficiency virus activity. Chem Pharm Bull (Tokyo) 43, 853-858.

Tanaka, D., Miyasaki, K. T. \& Lehrer, R. I. (2000). Sensitivity of Actinobacillus actinomycetemcomitans and Capnocytophaga spp. to the bactericidal action of LL-37: a cathelicidin found in human leukocytes and epithelium. Oral Microbiol Immunol 15, 226-231. 
van Houte, J. (1994). Role of micro-organisms in caries etiology. J Dent Res 73, 672-681.

Wade, D., Andreu, D., Mitchell, S. A., Silveira, A. M., Boman, A., Boman, H. G. \& Merrifield, R. B. (1992). Antibacterial peptides designed as analogs or hybrids of cecropins and melittin. Int J Pept Protein Res 40, $429-436$.

Wüthrich, K. (1986). NMR of Proteins and Nucleic Acids. New York: Wiley.
Yeaman, M. R. \& Yount, N. Y. (2003). Mechanisms of antimicrobial peptide action and resistance. Pharmacol Rev 55, 27-55.

Zasloff, M. (1992). Antibiotic peptides as mediators of innate immunity. Curr Opin Immunol 4, 3-7.

Zasloff, M. (2002). Antimicrobial peptides of multicellular organisms. Nature 415, 389-395.

Zhao, C., Liu, L. \& Lehrer, R. I. (1994). Identification of a new member of the protegrin family by cDNA cloning. FEBS Lett $346,285-288$. 